DOI https://doi.org/10.18551/rjoas.2017-12.41

\title{
ANALYSIS OF WATER QUALITY PARAMETERS FOR SEAWEED (EUCHEUMA COTTONII) FARMING SITE SUITABILITY IN MANDAR BAY, WEST SULAWESI, INDONESIA
}

\author{
Walinono Andi Rusdi ${ }^{1,2 *}$, Marsoedi ${ }^{3}$, Tjahjono Agus ${ }^{3}$, Semedi Bambang ${ }^{3}$ \\ ${ }^{1}$ Doctoral Program, Faculty of Fisheries and Marine Sciences, \\ University of Brawijaya, Indonesia \\ ${ }^{2}$ Fishery Agribusiness Studies program, State Agricultural Polytechnic Pangkajene Islands, \\ District Mandalle of Pangkep Regency, Indonesia \\ ${ }^{3}$ Graduate Program of Fisheries and Marine Sciences, Faculty of Fisheries and Marine \\ Sciences, University of Brawijaya, Indonesia \\ *E-mail: andirusdiwalinono1@gmail.com
}

\begin{abstract}
This study aims to analyze the water quality parameters for seaweed (Eucheuma cottonii) farming. The study was conducted in water areas of Mandar Bay for 3 months. Water quality samples were analyzed in the water quality laboratory of Politeknik Pertanian Negeri Pangkajene Kepulauan, South Sulawesi, Indonesia. The method used was explorative research by using survey method and direct measurement field. Determination of stations used GPS. The data obtained were analyzed according to environmental parameters to determine the site suitability with Geographic Information System approach. Six water quality parameters which did not meet the requirements for seaweed farming business, i.e. current velocity, dissolved oxygen, BOD, COD, Nitrate and phosphate were found. The total water areas of Polewali Mandar Subdistrict were 1.252.66 ha, the site with highly suitable rate was 65.39 ha and the site with marginally suitable rate was 1.187.27 ha. Based on the village area, Polewali village had highly suitable site of 13.16 ha and marginally suitable site of 231.89 ha, Wattang village had no highly suitable site of 0 ha and marginally suitable site of 126.22 ha, Lantora village had highly suitable site of 11.30 ha and marginally suitable site of 142.12 ha, Takatidung village had highly suitable site of 39.85 ha and marginally suitable site of 142.23 ha and Manding sub-district had highly suitable site of 1.08 ha and marginally suitable site of 34481 ha.
\end{abstract}

\section{KEY WORDS}

GIS, land suitability, Eucheuma cottonii seaweed, physical and chemical conditions.

Polewali Mandar is one of the seaweeds producers in West Sulawesi. Production of Eucheuma cottonii seaweed in Polewali Mandar Regency has decreased to date (DKP Polman, 2015). This potential needs to get priority handling in order to make a greater opportunity to increase aquaculture production in the future. Identification of the site feasibility for the aquaculture development is important for spatial planning in accordance with the allocation to avoid conflicts of interests between marine and fisheries sector and other sectors. The identification of the accurate site can also be used as a success indicator of the farming efforts in accordance with the type of commodity and farming technology to be applied (Dahuri, 2001).

Coastal development for seaweed farming activities cannot be separated from water suitability factor. The main obstacles in the development of seaweed farming in Indonesia are the water location incongruity, water quality parameter unsuitability, and feeling-based site of farming (Hartoko and Helmi 2004). Furthermore, Hardjowigeno (2001) argues that land suitability is the fitness of a given type of land for a defined use by determining the value (class) of land and land use patterns related with the potential of the territory, so more targeted land use can be used for business and sustainability.

An alternative analysis approach is used to make it easier to know the suitability of land in a large area or region with the application of Geographic Information System technology 
(Hambali, 2012). Furthermore, it is believed that based on spatial analysis with Geographic Information System (GIS) approach, land suitability class for seaweed farming could be obtained Longdill et al, (2008)

This study aims to analyze the water quality parameters for seaweed (Eucheuma cottonii) farming in the water areas of Mandar Bay, West Sulawesi. The results of this study are expected to be a reference material in the management of water quality for seaweed farming efforts in Mandar Bay, West Sulawesi.

\section{MATERIALS AND METHODS OF RESEARCH}

The research was conducted in October-December 2015 in a seaweed production area at Mandar Bay. The bay is located in $03^{\circ} 42^{1} 87^{11}-03^{\circ} 45^{1} 16^{11} \mathrm{~S}$ and $119^{\circ} 30^{1} 06^{11}-119^{\circ}$ $35^{1} 43^{11}$ E. Polewali Subdistrict, Polewali Mandar Regency, West Sulawesi Province, Indonesia.

This research was an explorative research. The researchers conducted surveys and direct measurements in the field by using quantitative approach with hypothesis testing. The testing aimed to collect data and information on the research location to obtain actual data related to seaweed farming activities in Mandar Bay (Sugiyono 2005).

Sampling was conducted on 12 stations by carrying out purposively sampling with consideration of seaweed farming (Figure 1). Each site of observation wherever possible represented or described the condition of the water areas. According to APHA (1998), before measurement and sampling, the determination of the coordinate point by using Global Positioning System (GPS) should be done first.

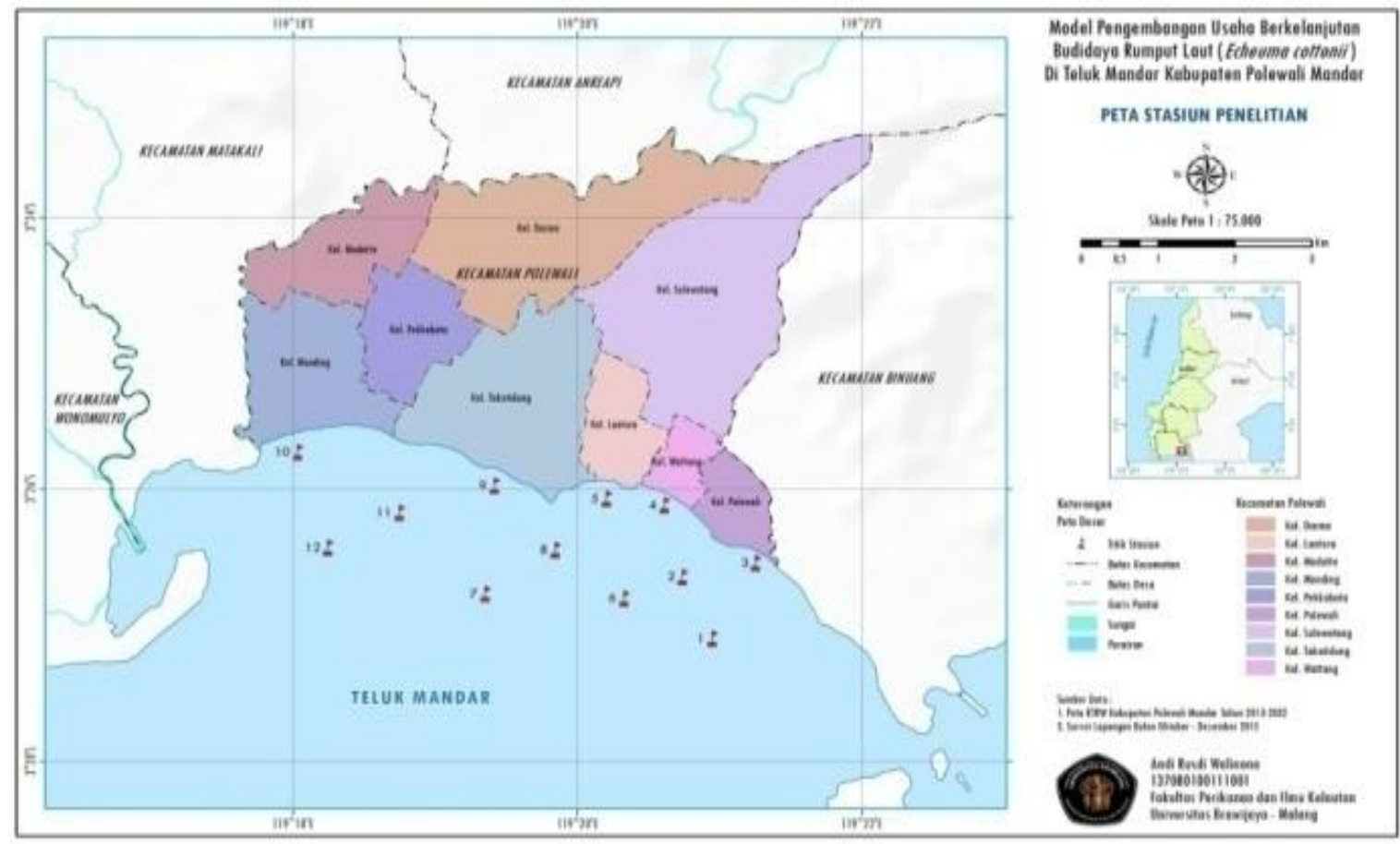

Figure 1 - Sampling Site

Data obtained in this research were primary and secondary data. Primary biophysical data were temperature, salinity, brightness, water depth, current velocity, directly-performed $\mathrm{pH}$ measurements, dissolved oxygen, nitrate, phosphate, BOD, and COD in the laboratory. For seaweed farmers, the data was obtained through interviews and questioners. Secondary data were obtained through Journals, Research Institutions, Earth Stations, Central Bureau of Statistics, and Department of Marine and Fisheries.

Conformity analysis was done based on utilization limiting parameter in terms of ecological aspect. The initial criteria were ecological factors such as temperature, salinity, 
brightness, water depth, current velocity, $\mathrm{pH}$, dissolved oxygen, COD, BOD, nitrate, phosphate, (Hartoko and Kangkan, 2009; Anwar and Burhanuddin, 2016; Semedi et al, 2016).

Based on the feasibility assessment system referred to Bakosurtanal (Badan Koordinasi Survei dan Pemetaan Nasional, National Coordinator for Survey and Mapping Agency) (1996) and DKP (Dinas Kelautan dan Perikanan, Department of Marine and Fisheries) (2002), the feasibility for seaweed farming is divided into four classes with 64.080.0 score is categorized Highly Suitable (S1), 48.0-63.9 score is categorized Moderately Suitable (S2), $32.0-47.9$ score is categorized as Marginally suitable (S3) and $<32.0$ score is categorized as Not Suitable (TS).

\section{RESULTS AND DISCUSSION}

Based on the results of water quality parameters measurement at the sampling sites in 12 stations, the temperature range was between $30.0-30.6^{\circ} \mathrm{C}$, the salinity range was between 29.6-30.6 ppt, and the $\mathrm{pH}$ was in the range of 7.28-7.96. All three parameters were in the highly suitable range for seaweed farming.

Brightness range between 3.5-9.0 m which was a highly suitable range for seaweed farming was located at stations $1,2,6$, and 8 , while other stations were not qualified for seaweed farming. Water depth range between 1.9-8.5 $\mathrm{m}$ which was a highly suitable range for seaweed farming was at station 2,5 , and 8 , while other stations averagely did not meet the requirements for seaweed farming.

Biochemical Oxygen Demand (BOD) values range between $5.88-9.75 \mathrm{mg} / \mathrm{L}$ which was in the range of organic material contamination was found at station $1,2,5,6,7,8$, and 11. Chemical Oxygen Demand (COD) values range was between $108-117 \mathrm{mg} / \mathrm{L}$. The value was in the range of pollution which could be found at the station $3,4,5,9,10,11$, and 12 . Figure 2 presents a more detailed result.

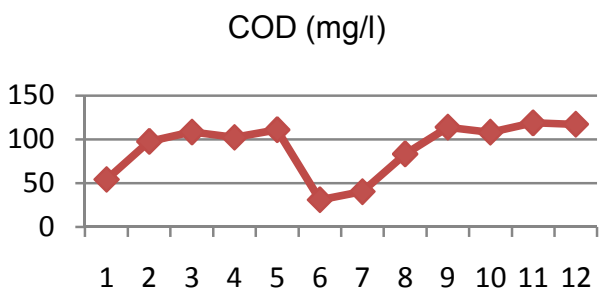

Figure 2 - COD Range Curve

\section{$\mathrm{CV}(\mathrm{cm} / \mathrm{dtk})$}

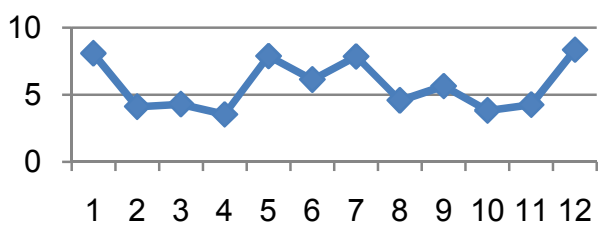

Figure 3 - Current velocity range curve

Current velocity range was between $3.5-8.3 \mathrm{~cm} / \mathrm{s}$ (Figure 3), DO range was between 2.05-2.45 mg/L (Fig 4), and nitrate range was between $0.00010-0.00315 \mathrm{mg} / \mathrm{L}$ (Fig 5). The phosphate range was between $0.0069-0.1607 \mathrm{mg} / \mathrm{L}$. The four water quality parameters were in the not suitable range and did not meet the requirements for seaweed farming in Mandar Bay waters.

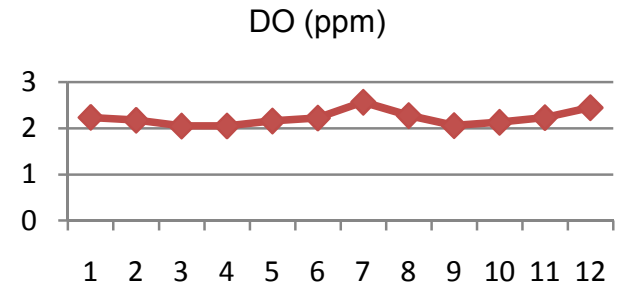

Figure 4 - DO Range curve

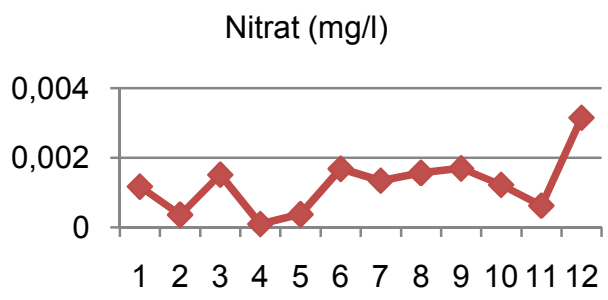

Figure 5-1 Nitrate Range Curve 
Based on the spatial (overlay) analysis results of water suitability for seaweed farming in Mandar Bay, West Sulawesi with the seaweed growth determinants such as water depth, brightness, current velocity, temperature, salinity, $\mathrm{pH}$ and DO, Nitrate, Orthophosphate, BOD, and COD, it was found that the total water areas of Polewali Mandar Subdistrict was 1.252.66 ha, the site with highly suitable rate was 65.39 ha and the site with marginally suitable rate was 1.187.27 ha (Figure 6).

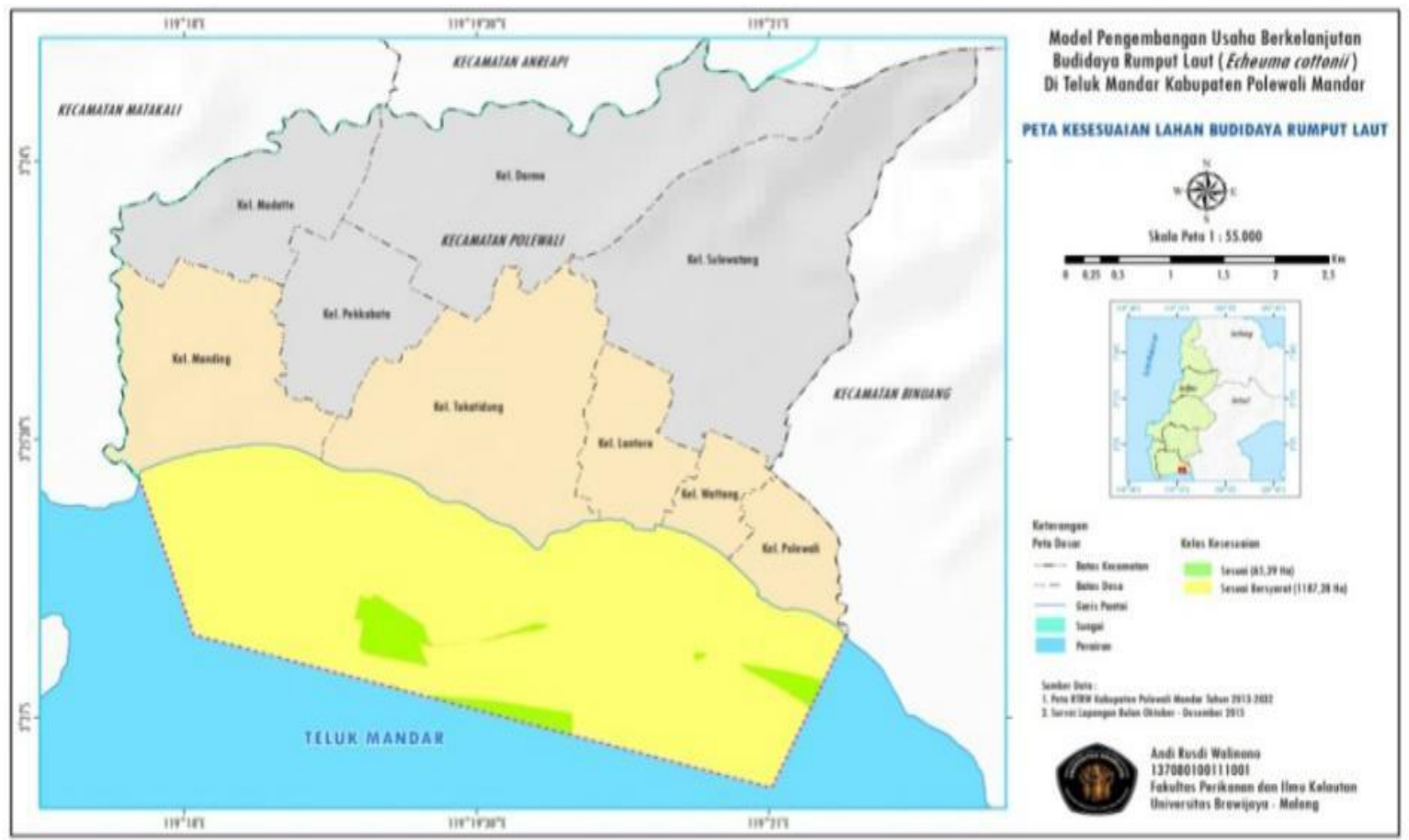

Figure 6 - Site suitability location of Mandar Bay water areas are in green color

Based on the subdistrict areas which is divided into five villages, Polewali village had highly suitable site of 13.16 ha and marginally suitable site of 231.89 ha, Wattang village had no highly suitable site of 0 ha and marginally suitable site of 126.22 ha, Lantora village had highly suitable site of 11.30 ha and marginally suitable site of 142.12 ha, Takatidung village had highly suitable site of 39.85 ha and marginally suitable site of 142.23 ha and Manding sub-district had highly suitable site of 1.08 ha and marginally suitable site of 34481 ha.

\section{CONCLUSION}

Water quality parameters which did not meet the requirements for seaweed farming were namely current velocity, dissolved oxygen, BOD, COD, Nitrate and phosphate.

The total water areas of Polewali Mandar Subdistrict were 1.252.66 ha, the site with highly suitable rate was 65.39 ha and the site with marginally suitable rate was 1.187 .27 ha. Based on the village area, Polewali village had highly suitable site of 13.16 ha and marginally suitable site of 231.89 ha, Wattang village had no highly suitable site of 0 ha and marginally suitable site of 126.22 ha, Lantora village had highly suitable site of 11.30 ha and marginally suitable site of 142.12 ha, Takatidung village had highly suitable site of 39.85 ha and marginally suitable site of 142.23 ha and Manding sub-district had highly suitable site of 1.08 ha and marginally suitable site of 34481 ha.

\section{REFERENCES}

1. Anwar. A and Burhanuddin, 2016. The Parameters Analysis of Physics, Chemistry and Biology in Sealayar Marine For Feasibility Seaweed Cultivation Eucheuma cottonii. J of Oceans and Oceanography V.10 (2) : 287-297 
2. APHA (American Public Health Association). 1998. Standard Methods for Examination of Water and Wastewater. Twentieth edition. APHA - AWWA - WEF, Washington, DC. $1,185 \mathrm{pp}$.

3. Badan Koordinasi Survei dan Pemetaan Nasional, 1996. Pengembangan prototipe wilayah pesisir dan marine Kupang Nusa Tenggara Timur. Pusat Bina Aplikasi Inderaja dan SIG. Jakarta (ID): Bakosurtanal.

4. Dahuri R, J. Rais, SP. Ginting dan MJ. Sitepu. 2001. Pengelolaan Sumberdaya Wilayah Pesisir dan Lautan Secara Terpadu. Jakarta PT. Pradnya Paramita..

5. DKP Polman, 2015. Data Potensi Dan Produksi Perikanan Budidaya Laut. Dinas Kelautan dan Perikanan Kabupaten Polewali Mandar.

6. Departemen Kelautan dan Perikanan, 2002, Modul Sosialisasi dan Orientasi Penataan Ruang, Laut, Pesisir dan Pulau-Pulau Kecil. Ditjen Pesisir dan Pulau-Pulau Kecil. Direktorat Tata Ruang Laut, Pesisir dan Pulau-Pulau Kecil. Jakarta.

7. Direktorat Jenderal Perikanan Budidaya. 2002. Strategi Pengembangan Budidaya Rumput Laut dalam Rangka Mendukung Protekan 2002. Di dalam Temu Konsultasi Teknis Pengembangan Budidaya Rumput Laut Lintas Sektor dan Subsektor. Departemen Kelautan dan Perikanan RI. Jakarta.

8. Hambali, M. 2012. Aplikasi SIG Untuk Kesesuaian Kawasan Budidaya Rumput Laut Eucheuma cottonii dengan Metode Lepas Dasar di Pulau Mantang, Kecamatan Mantang. Kabupaten Bintang.

9. Hardjowigeno S. 2001. Kesesuaian lahan dan perencanaan tata guna tanah. Bogor (ID): Faperta IPB.

10. Hartoko. A and M. Helmi. 2004. Development of digital multilayer ecological model for padang coastal water (West Sumatera). J of Coastal Development. 7.(3):129-136.

11. Hartoko.A and Kangkan. 2009. Spatial Modeling For Mariculture Site Selection Based on Ecosystem Parameters at Kupang Bay, East Nusa Tenggara, Indonesia. J of Remote Sensing and Earth Sciences. 6:57-64

12. Longdill, P.C, Terry R.Healy, Kerry P.Black. (2008) An integrated Gis Approch for Sustainable aquaculture Management area Site Selection. Journal homepage. Elsevier. Ocean and Coastal Management. 51: 612-624.

13. Semedi, B, Da Kosta and Mahmudi, M. 2016. Feasibility of Seaweed (Kapaphycus alvarezii) Maricultur Using Geografic Information System In Hading Bay, East Flores Indonesia. J of Natural Environment and pollution Technology.15.(4) : 1347-1349.

14. Sugiyono. 2005. Metode Penelitian Kualitatif. Bandung (ID): Alfabeta. 